\title{
A causal role for hyperinsulinemia in obesity
}

\author{
Nicole M Templeman', Søs Skovsø', Melissa M Page1, Gareth E Lim¹ and \\ James D Johnson ${ }^{1,2}$ \\ 'Department of Cellular and Physiological Sciences, Diabetes Research Group, Life Sciences Institute, \\ University of British Columbia, Vancouver, British Columbia, Canada \\ IInstitute for Personalized Therapeutic Nutrition, Vancouver, British Columbia, Canada
}

Correspondence should be addressed

to J D Johnson

Email

James.d.johnson@ubc.ca

\begin{abstract}
Insulin modulates the biochemical pathways controlling lipid uptake, lipolysis and lipogenesis at multiple levels. Elevated insulin levels are associated with obesity, and conversely, dietary and pharmacological manipulations that reduce insulin have occasionally been reported to cause weight loss. However, the causal role of insulin hypersecretion in the development of mammalian obesity remained controversial in the absence of direct loss-of-function experiments. Here, we discuss theoretical considerations around the causal role of excess insulin for obesity, as well as recent studies employing mice that are genetically incapable of the rapid and sustained hyperinsulinemia that normally accompanies a high-fat diet. We also discuss new evidence demonstrating that modest reductions in circulating insulin prevent weight gain, with sustained effects that can persist after insulin levels normalize. Importantly, evidence from long-term studies reveals that a modest reduction in circulating insulin is not associated with impaired glucose homeostasis, meaning that body weight and lipid homeostasis are actually more sensitive to small changes in circulating insulin than glucose homeostasis in these models. Collectively, the evidence from new studies on genetic loss-of-function models forces a re-evaluation of current paradigms related to obesity, insulin resistance and diabetes. The potential for translation of these findings to humans is briefly discussed.
\end{abstract}

\section{Phylogeny and complexity of insulin-like peptides and the insulin signaling network}

Insulin/Insulin-like growth factor 1 (IGF1)-like signaling is evolutionarily conserved, and its many functions are shared across species. This pathway plays a critical role in coordinating nutrient availability with energy storage, body size and longevity in both invertebrates and vertebrates (Fontana et al. 2010, van Heemst 2010, Rideout et al. 2015). Seminal studies have shown that worms or flies with reduced insulin peptides or insulin signaling are leaner and live longer (Kenyon et al. 1993, Clancy et al. 2001).

Invertebrates produce numerous insulin-like peptides: there are at least 38 genes encoding putative insulin-like peptides in Caenorhabditis elegans (Pierce et al. 2001), and eight known genes in Drosophila melanogaster (Brogiolo et al. 2001). In mammals, the superfamily of insulin-like genes includes insulin, two insulin-like 
growth factors (IGF1 and IGF2), relaxins (three relaxin genes in humans) and four additional insulin-like peptides (insulin-like peptides 3-6; Nakae et al. 2001, Shabanpoor et al. 2009, Fernandez \& Torres-Aleman 2012). These mammalian peptides appear to be derived from a shared ancestral gene and have structural similarities, although the known biological functions of the majority of these peptides appear largely distinct from those of insulin and IGF1 (Shabanpoor et al. 2009). However, a recent study showed that insulin-like peptide 5 produced by enteroendocrine cells acts as an orexigenic hormone with circulating levels that change in response to feeding status, which suggests that this peptide also plays a role in coordinating energy homeostasis (Grosse et al. 2014).

Although most mammals and humans have only a single 'insulin' gene, mice and rats have two insulin peptides that are produced from separate insulin genes (Soares et al. 1985, Shiao et al. 2008). Ins2 is the ancestral insulin gene that is analogous to human INS, whereas rodent-specific Ins1 appears to have originated from the transposition of a reverse-transcribed, partially processed Ins2 mRNA (Soares et al. 1985). Fully processed INS1 and INS2 peptides differ at the level of two B-chain amino acids, with additional differences evident in their C-peptides (Wentworth et al. 1986). Despite sharing sequence homology upstream of the transcription initiation site (Wentworth et al. 1986, Melloul et al. 2002), Ins1 and Ins2 do have notable differences with respect to certain promoter elements, expression patterns, translational efficiency and imprinting status (Wentworth et al. 1986, Linde et al. 1989, Deltour et al. 1995, Hay \& Docherty 2006, Meur et al. 2011, Mehran et al. 2012). Ins2 can be detected earlier in murine development and has a broader tissue distribution (Deltour et al. 1993, Fan et al. 2009, Mehran et al. 2012). Murine Ins1 expression and promoter activity are largely restricted to the pancreas (Mehran et al. 2012, Thorens et al. 2015), and it does not contribute as much to pancreatic insulin production as Ins2, except in the mouse embryo during the early stages of pancreatic development (Wentworth et al. 1986, Linde et al. 1989, Deltour et al. 1993, Bengtsson et al. 2005). Complete inactivation of both Ins genes in mice (i.e. Ins $1^{--}$:Ins $2^{--}$) leads to severe diabetes and death within several days of birth, or weeks after conditional insulin gene deletion (Duvillie et al. 1998, Szabat et al. 2016). However, genetic inactivation of either Ins gene alone has not been reported to be associated with significant metabolic deficiencies (Leroux et al. 2001, Mehran et al. 2012, Templeman et al. 2015, 2016, Dionne et al. 2016). Instead, there is a partial compensatory elevation of
mRNA and protein of the corresponding non-deleted Ins gene, and increased beta-cell mass, which suggests a degree of redundancy between Ins1 and Ins2 (Leroux et al. 2001, Mehran et al. 2012, Templeman et al. 2015, 2016, Dionne et al. 2016). However, there is evidence to suggest that Ins1 may have been subjected to positive selective mechanisms to maintain the two-Ins gene system in mice (Shiao et al. 2008), and it is unclear whether INS1 and INS2 or their peptide products have distinct functional roles. In unpublished studies, we have found that Ins1 and Ins 2 peptides had similar biological activities using 3T3L1 pre-adipocyte differentiation as an assay. We and others have taken advantage of the unique properties of the two insulin genes to gain novel insight into the biology of this essential hormone.

Mammalian insulin/IGF1 signaling involves multiple receptors, and a network of signaling pathways can be triggered through activation of each receptor subtype, with the added complexity of interactions and crosstalk between the downstream pathways (White 2003, van Heemst 2010). The classical tyrosine kinase receptor ligands in mammals are insulin and IGF1, which bind with variable affinity to the primary mammalian insulin/IGF1 tyrosine kinase receptors, consisting of the insulin receptor (IR), which has two functionally distinct splice isoforms (IRa and IRb), and the IGF1 receptor (IGF1R; van Heemst 2010). Moreover, as these receptors are tetrameric proteins, functional hybrid heterodimers can form between insulin and IGF1 receptor subunits (e.g. IRa:IGF1R, IRb:IGF1R; van Heemst 2010). Receptor activation and subsequent phosphorylation of proximal effectors, such as the scaffolding proteins insulin receptor substrate (IRS) 1 or IRS2, initiate signal transduction via two major branches of insulin/IGF1 signaling: phosphatidylinositol 3-kinase (PI3K)/AKT and the mitogen-activated protein kinase (MAPK) pathways (Taniguchi et al. 2006). The precise mechanisms differentiating the downstream signaling of insulin receptors from IGF1 receptors have not been delineated (Nakae et al. 2001). However, insulin is widely considered to be the primary ligand of interest with respect to metabolic processes, despite the improbability of there being a complete divergence between the functions of insulin and IGF1 (Werner et al. 2008, Fu et al. 2013).

\section{Insulin as a key metabolic hormone}

Insulin plays fundamental and conserved roles in maintaining energy homeostasis (Fontana et al. 2010, van Heemst 2010). Since the discovery of insulin in 1922

Published by Bioscientifica Ltd 
(Banting et al. 1922), the majority of research pertaining to this hormone has revolved around the two diseases of absolute and relative insulin insufficiency, known as type 1 diabetes and type 2 diabetes, respectively. Lately, there has been a resurgence of interest in conditions associated with excessive insulin production. Hyperinsulinemia, which for the purpose of this review will broadly refer to elevated basal and/or stimulated insulin secretion, is associated with obesity, and is nearly universal in the early stages of type 2 diabetes (Tabak et al. 2009). However, these correlative associations do not provide information as to whether excess insulin might be a causal contributor to obesity and its associated complications.

Circulating insulin levels are rapidly adjusted in response to nutrients in the blood, including glucose, and undergo sustained basal alterations in response to chronic demand (Werner et al. 2008, Fu et al. 2013). The acute increase in circulating insulin induced by food intake promotes nutrient storage in its major peripheral target tissues, primarily by stimulating: (1) glucose uptake in adipose tissue and muscle; (2) glycolysis and glycogen synthesis in muscle and liver; (3) lipogenesis in adipose tissue and liver and (4) protein synthesis in muscle and liver. Conversely, insulin has repressive functions on glycogenolysis, lipolysis and protein breakdown, as well as gluconeogenesis and ketogenesis in the liver (Taniguchi et al. 2006, Cheng et al. 2010, Czech et al. 2013). Insulin may also exert local autocrine effects to promote beta-cell growth and survival, as well as influence its own production and secretion (Fig. 1; Luciani \& Johnson 2005, Johnson et al. 2006, Beith et al. 2008, Leibiger et al. 2008, Mehran et al. 2012, Wang et al. 2013). In addition to its peripheral effects, insulin may affect energy balance and peripheral metabolism via central actions, such as through modulation of food intake; insulin signaling in the brain has been extensively reviewed elsewhere (e.g. Stockhorst et al. 2004, Schwartz \& Porte 2005, Fernandez $\&$ Torres-Aleman 2012, Lee et al. 2016). Insulin clearly has essential roles in regulating energy balance and metabolic pathways, but there is still much to be learned about these and other critical functions of this hormone.

\section{Hyperinsulinemia in the etiology of insulin resistance and type 2 diabetes}

Type 2 diabetes is defined as chronically elevated blood glucose that results from insufficient insulin production or impaired responsiveness to insulin (McGarry 1992, Prentki \& Nolan 2006). Underlying factors that contribute to both obesity and susceptibility to type 2 diabetes include genetic and epigenetic components, lifestyle and environmental conditions (McCarthy 2015). Chronic fuel surplus can lead to type 2 diabetes when there is a failure to compensate by adequately elevating insulin levels to meet demand (Prentki \& Nolan 2006, Nolan et al. 2013, 2015). A decline in beta-cell function and/or mass is required for the onset of full-blown diabetes, and progression toward this state appears to be perpetuated by the metabolic disruptions associated with impaired tissue responsiveness to circulating insulin (Prentki \& Nolan 2006, Nolan et al. 2011, 2015, Fu et al. 2013, Johnson \& Olefsky 2013). The term 'insulin resistance' is widely used to specify an impairment of glucose disposal in response to insulin stimulation; however, this term is misleading when used broadly, because not all insulinregulated processes are similarly affected in the insulinresistant state that is associated with glucose intolerance (Saltiel \& Kahn 2001, Biddinger \& Kahn 2006). It has also been proposed that mild insulin resistance can be beneficial and protective, at least early in the disease progression (Nolan et al. 2015). Insulin resistance within tissues can arise at multiple levels of the insulin signaling pathway (Johnson \& Olefsky 2013). Insulin resistance can also be caused by insulin receptor desensitization and removal from the plasma membrane (Knutson et al. 1983, Boothe et al. 2016).

Peripheral insulin resistance is closely related to elevated circulating insulin levels (Prentki \& Nolan 2006, Shanik et al. 2008), and both of these features are linked to glucose intolerance (Nolan et al. 2011, Fu et al. 2013, Johnson \& Olefsky 2013). Insulin resistance may be modulated by oscillatory dynamics of insulin secretion (Marsh et al. 1986, Shanik et al. 2008), and indeed, the loss of pulsatile insulin secretion is one of the earliest detectable defects in individuals who are at risk for type 2 diabetes (O'Rahilly et al. 1988, Satin et al. 2015). Currently, it is unclear whether hyperinsulinemia or altered insulin secretion dynamics play causal roles in the progression of type 2 diabetes. Theoretically, relative hyperinsulinemia could be maladaptive by enhancing weight gain, contributing to beta-cell exhaustion, or by exacerbating insulin receptor desensitization (i.e. insulin resistance).

Another interesting possibility is that insulin resistance at the level of the beta-cells could play a role in hyperinsulinemia, obesity, insulin resistance and type 2 diabetes (Fig. 1). Knockout mice lacking Irs1 or Akt gene function exhibit basal hyperinsulinemia and, in some cases, increased beta-cell mass (Kido et al. 2000,

Published by Bioscientifica Ltd 


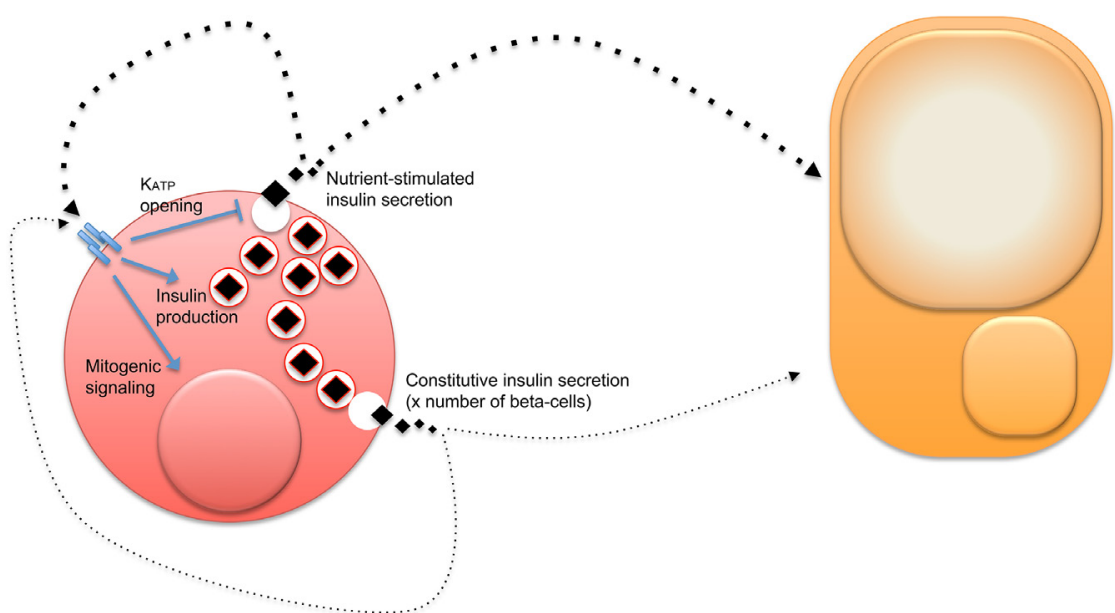

\section{Figure 1}

Insulin's effects are exerted through direct actions on target cells such as adipocytes, and also through autocrine feed-back on beta-cells. The number and function of beta-cells dictate insulin secretion levels and patterns that control adipogenesis and lipid homeostasis.
Bernal-Mizrachi et al. 2004), thereby mimicking the early stages in type 2 diabetes, but this concept should be tested directly with the insulin receptor and specific Cre deleter models. It has been shown that insulin acutely inhibits beta-cell electrical activity (Khan et al. 2001), meaning that local loss of insulin signaling might be expected to induce relative hyperinsulinemia. Indeed, insulin reduces its own secretion in healthy humans, but not in subjects that were obese (Cavallo-Perin et al. 1993). Human islets isolated from donors with type 2 diabetes were reported to have 50\% reduced INSR expression (Gunton et al. 2005), but it is not known whether insulin receptors or insulin receptor signaling is affected in islets from hyperinsulinemic, obese, prediabetic individuals.

Obesity is often associated with peripheral insulin resistance, and with hyperinsulinemia. Indeed, it is difficult to conceptually or experimentally separate the phenomena of hyperinsulinemia and insulin resistance. The commonly accepted paradigm proposes that the hyperbolic relationship between impairment of insulinstimulated glucose uptake and insulin secretion signifies that hyperinsulinemia is a compensatory response to prevent hyperglycemia when peripheral tissues are failing to take in excess glucose due to conditions resulting from obesity (Shanik et al. 2008). However, the chronology of obesity, hyperinsulinemia and insulin resistance is not always clear (Shanik et al. 2008). Characteristics of the obese state, such as toxic accumulation of lipids in nonadipose tissue and increased levels of proinflammatory cytokines, can induce or exacerbate insulin resistance, and the resultant elevated blood glucose has the potential to stimulate increased insulin secretion (Saltiel \& Kahn 2001, Biddinger \& Kahn 2006, Johnson \& Olefsky 2013). On the other hand, clinical and experimental evidence indicates that hyperinsulinemia can precede and promote both obesity (Genuth et al. 1971, Odeleye et al. 1997, Corkey 2012, Mehran et al. 2012) and insulin resistance or dysglycemia (Cusin et al. 1990, Le Stunff \& Bougnères 1994, Dankner et al. 2009). Moreover, drugs that alleviate or prevent hyperinsulinemia can lead to weight loss (Alemzadeh et al. 1996, 1998, Lustig et al. 2005) and can enhance insulin-stimulated glucose uptake (Alemzadeh et al. 1996, Gray et al. 2010, Pedersen et al. 2015). Measured baseline insulin levels within healthy human and mouse populations are subject to wide variance (McAuley et al. 2001, Li et al. 2006, Berglund et al. 2008, Templeman et al. 2016), and diet intervention studies have indicated that obese individuals with the highest insulin secretion respond best to diets that reduce postprandial glycemia and insulinemia, whereas obese subjects with relatively lower insulin levels experience equivalent weight loss on low-fat diets (Pittas et al. 2005, Ebbeling et al. 2007). Collectively, these studies suggest that insulin has more of a causal role in perpetuating obesity and peripheral insulin resistance than is widely supposed.

\section{Direct mechanisms by which insulin may influence obesity}

The expansion of white adipose tissue (WAT) that defines obesity can occur through both adipocyte hypertrophy (lipid filling) and hyperplasia (adipogenesis or increased differentiation of adipocyte precursor cells into adipocytes), but the mechanisms controlling these processes have not yet been fully delineated (Berry et al. 2014, Lim et al. 2015). Biochemical studies have shown that insulin plays key roles in regulating white adipocyte lipid

Published by Bioscientifica Ltd 


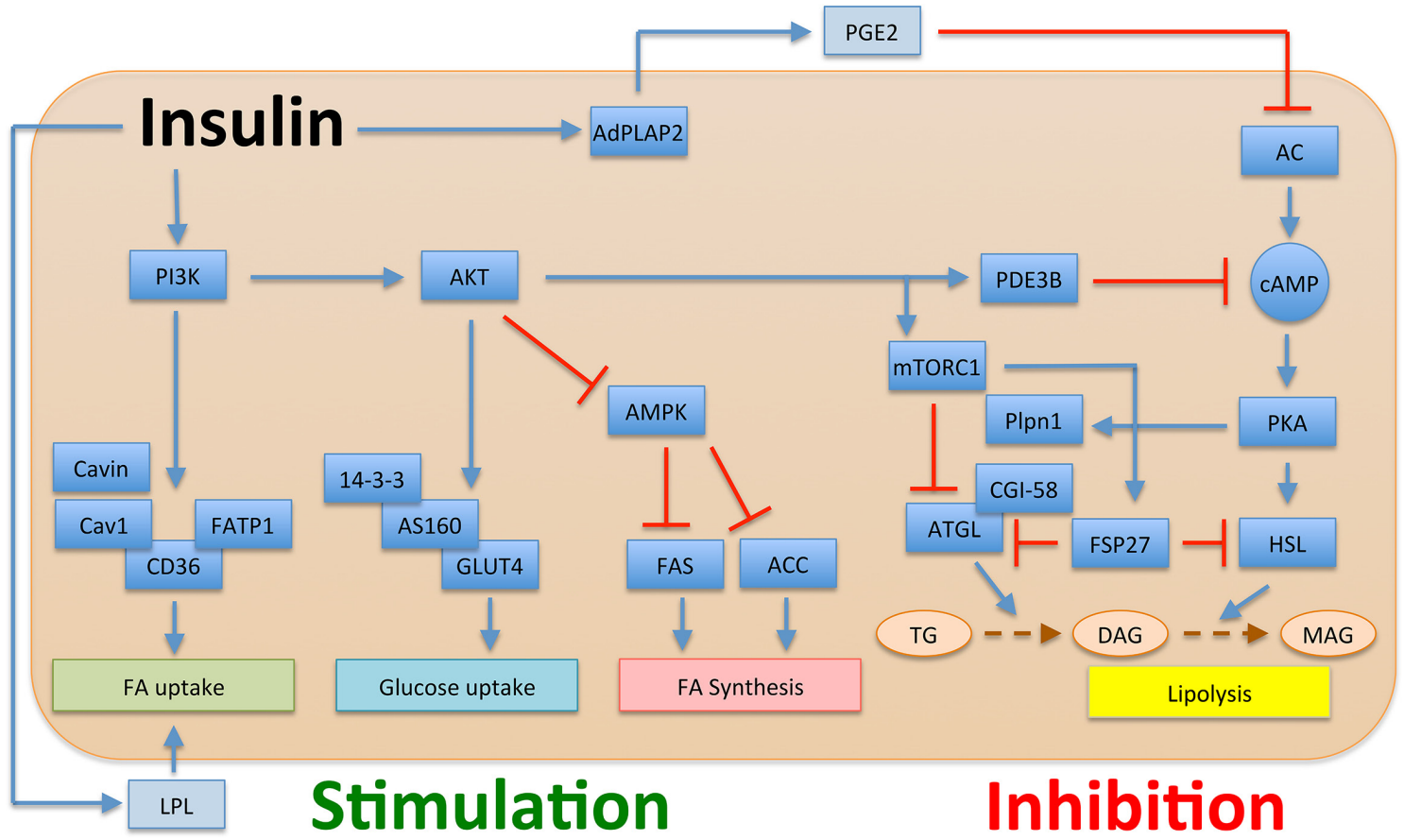

Figure 2

Insulin acts through multiple mechanisms to stimulate lipid uptake and storage and to inhibit lipid breakdown. Additional details have been expertly reviewed by Czech et al. (2013).

accumulation, by inhibiting lipolysis as well as promoting fatty acid uptake and triglyceride synthesis (lipogenesis) and also by stimulating the expression of genes involved in lipid uptake and storage (Kersten 2001, Czech et al. 2013) (Fig. 2). Over a longer term, insulin signaling can drive adipogenesis, an orchestrated progression of events involving transient expression of the transcription factors CCAAT/enhancer-binding protein (C/EBP) $\beta$ and C/EBPS leading to induction of the master adipogenic regulators $\mathrm{C} / \mathrm{EBP} \alpha$ and peroxisome proliferator-activated receptor (PPAR) $\gamma$ (Cook \& Cowan 2008, Berry et al. 2014, Lim et al. 2015). Recently, it has also been shown that hyperinsulinemia promotes adipose tissue inflammation in mice, which contributes to disruption of metabolic processes such as de novo lipogenesis in WAT (Pedersen et al. 2015). Although the mechanisms guiding WAT growth are not fully understood, insulin appears to have the potential to influence several prominent steps. Indeed, deletion of insulin receptors from WAT protects mice from obesity, demonstrating a fundamental requirement for insulin in adipocyte differentiation and/or hyperplasia and/or hypertrophy (Katic et al. 2007, Boucher et al. 2012, Softic et al. 2016).

There are multiple types of adipose tissue with distinct functions, spatial distribution and contributions to obesity, and it is not clear whether insulin affects all types of adipocytes similarly. WAT is the primary type of adipose tissue that serves as an energy reserve, and WAT also secretes an array of factors with autocrine, paracrine and endocrine functions (Berry et al. 2014). Subcutaneous and visceral depots of WAT have distinct characteristics, differing in cellular composition, innervation, metabolic characteristics and secretory profile; in general, visceral WAT is more implicated in perpetuating metabolic dysfunction, compared to subcutaneous WAT (Lee et al. 2013, Lim et al. 2015). Interestingly, insulin treatment may have selective trophic effects on subcutaneous WAT when compared with visceral WAT in a rat model of latestage type 2 diabetes (Skovso et al. 2015). The mechanisms regulating the specific expansion of distinct WAT depots are not well understood, although physiological factors such as age and sex have an influence on adipose tissue distribution (Fuente-Martin et al. 2013, Lee et al. 2013, Jeffery et al. 2016, Kwok et al. 2016). For instance, central adiposity tends to increase with aging, and many of the pathologic conditions or diseases associated with obesity, including glucose intolerance and type 2 diabetes, insulin resistance, a proinflammatory state, coronary heart disease, hypertension, atherosclerosis and some cancers, are also associated with aging (Ebbeling et al. 2007). It seems that certain stages of life, such as the perinatal period and adolescence, are particularly

Published by Bioscientifica Ltd 
influential for determining the metabolic and adipocyte characteristics and thus shaping future susceptibility to obesity (Lawlor \& Chaturvedi 2006, Buyken et al. 2014, Templeman et al. 2015).

Brown adipose tissue (BAT) and the brown-like adipocytes that can be found in some WAT depots are distinguished from WAT by a marked capacity to uncouple the electron transport chain-generated proton gradient from ATP synthesis, and thus expend energy through thermogenesis (Beranger et al. 2013). Although increasing the activity of BAT or expansion of brownlike adipocytes has been proposed as a treatment for obesity, the overall contribution of BAT and brownlike adipocytes to whole body metabolism is still being debated (Chondronikola et al. 2016, Labbe et al. 2016). BAT-specific insulin receptor knockout in mice results in the loss of fat-burning BAT tissue, illustrating an important role for insulin in this tissue (Guerra et al. 2001). Overall, there is ample evidence supporting effects of insulin signaling in adipose tissue that could influence the onset and development of obesity.

\section{Prevention of obesity in mice genetically incapable of sustained hyperinsulinemia}

Although clinical and experimental evidence indicated that hyperinsulinemia could precede and promote obesity (Genuth et al. 1971, Odeleye et al. 1997, Corkey 2012), what was previously missing from the field was a genetic loss-of-function experiment in a mammalian model system that could directly establish the causal requirement for hyperinsulinemia in diet-induced obesity. To address this unmet need, we designed a series of studies in which we modulated the insulin gene dosage, and, to varying extents, levels of circulating insulin in mice (Mehran et al. 2012, Templeman et al. 2015, 2016). The fact that mice have two insulin genes allowed us to compare effects over a range of insulin reductions, and to avoid the compensation that occurs between the two insulin genes.

In the first such study, we used mice that were null for the Ins2 gene to focus attention only on insulin coming from the pancreas (Mehran et al. 2012). Thus, on the Ins2-null background, we compared Ins1 heterozygous mice (Ins $1^{+--}:$Ins $2^{-/-}$mice) to their littermate controls that had both Ins1 alleles (Ins $1^{+/+}$:Ins $2^{-/-}$mice) for one year, and we confirmed that the Ins1 $1^{+--}$:Ins2-/- mice exhibited the expected sustained reduction in circulating insulin, which was associated with reduced beta-cell mass. Remarkably, we found that male Ins $1^{+--}:$Ins $2^{-/-}$mice were completely protected from diet-induced obesity, as well as related sequelae including fatty liver, over this time frame. We observed an increase in energy expenditure in mice with less insulin, associated with browning of WAT, but no differences in food intake. Interestingly, control female Ins $1^{+/+}:$Ins2 $2^{-/-}$mice did not develop significant hyperinsulinemia in a comparison between these highfat and moderate-fat diets, so we were unable to test our hypothesis in females. It should be noted that male and female mice with only a single Ins1 allele (on an Ins2-null background) had relatively normal glucose homeostasis when housed in our conventional facility (Mehran et al. 2012), but diabetes is now found in over half of the male Ins1+--:Ins2--- mice after they were rederived into new 'modified barrier' and 'specific pathogen-free' facilities. The reason for this increased diabetes susceptibility in male mice with a single remaining Ins1 allele is not clear, but could be related to gut microbiota, environmental stresses or genetic drift within this strain. Notwithstanding, the results of this first study demonstrated for the first time in any mammal that hyperinsulinemia is required for weight gain.

In a second study, we studied female Ins $1^{-/-}: \operatorname{Ins} 2^{+/-}$ experimental mice and their littermate Ins $1^{-1-}:$ Ins $2^{+/+}$ controls for one year. In this experiment, reduced Ins2 gene dosage led to a transient decrease in circulating insulin that was significant at 8 and 28 weeks, but had returned to hyperinsulinemic levels at one year (Templeman et al. 2015). This transient reduction of dietinduced hyperinsulinemia provided sustained protection from obesity, although in this less-severe model of insulin reduction, we did not observe evidence of significant browning of WAT (Templeman et al. 2015). A pilot study provided evidence that partial normalization of INS2 peptide levels, via mini-osmotic pump, was sufficient to partially reverse the protective anti-obesity effects of reducing Ins2 gene dosage.

Our third study focused on males with Ins $1^{-/-}: \operatorname{Ins} 2^{+/-}$

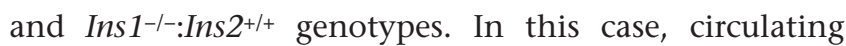
insulin levels were hypervariable compared with their female littermates, and were not significantly suppressed by reducing insulin gene dosage. The wide variation in circulating insulin in these male mice is similar to human populations and other mouse studies (Li et al. 2006, Berglund et al. 2008). Although this meant we could not test the hypothesis by comparing the body weight means

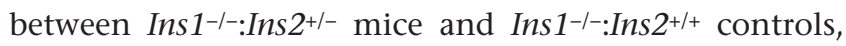
we still observed a significant positive correlation between body mass and fasting insulin levels in one-year-old male mice (Templeman et al. 2016).

Published by Bioscientifica Ltd 
These three studies, alongside data from mice with insulin receptor knock-out in adipose tissue (Katic et al. 2007, Boucher et al. 2012), strongly support the concept that excess insulin contributes to diet-induced obesity. Moreover, across multiple models, we found that obesity and lipid homeostasis are more sensitive to small changes in circulating insulin levels than glucose homeostasis. Collectively, these experiments also fit well with clinical and pre-clinical studies demonstrating that therapy with long-acting insulin analogues leads to weight gain, and with small trials showing weight loss with drugs that reduce insulin secretion (Alemzadeh et al. 1998, Lustig et al. 2005, ORIGIN Trial Investigators et al. 2012, Skovso et al. 2015). For example, a recent investigation reported that chronic insulin infusion via mini-osmotic pump leads to WAT expansion in mice (Rajan et al. 2016). Clearly, more work needs to be done, but the idea that insulin plays an important role in lipid homeostasis in vivo appears to be broadly supported.

\section{Nutritional regulation of insulin secretion}

Circulating insulin levels are affected by nutrients and numerous circulating factors, such as certain amino acids, fatty acids, sex hormones, melatonin, leptin, growth hormone, glucose-dependent insulinotropic polypeptide and glucagon-like peptide 1 (Melloul et al. 2002, Fu et al. 2013). Insulin levels can be tempered through stimulation or repression of its secretion, and insulin production is also subject to modulation, at the level of transcription, mRNA stability, translation and processing (Melloul et al. 2002, Fu et al. 2013). Basal insulin levels are also modulated chronically through changes in the number of beta-cells and their differentiation status (Szabat et al. 2012). One of the unexpected insights from our studies on insulinmutant mice is that although differences in gene dosage (and therefore insulin synthesis) usually translate into measurable changes in insulin secretion in the long-term (Mehran et al. 2012, Templeman et al. 2015), this is not always the case (Templeman et al. 2016). Both stimulated and basal insulin secretion are under multifactorial control and can be modulated through numerous means.

Although the carbohydrate glucose is clearly a dominant insulin secretagogue in adult beta-cells, evidence indicates that other sugars and non-carbohydrate substrates can also elicit significant insulin secretion under some conditions. For example, free fatty acids can acutely stimulate insulin secretion in some individuals, either alone or in the context of elevated glucose levels
(Paolisso et al. 1995, Carpentier et al. 1999, Jeffrey et al. 2008, Staaf et al. 2016). Prolonged exposure to high levels of lipids can also increase the number of beta-cells and induce fasting hyperinsulinemia in some rodent models (Fontes et al. 2010). Exposure to free fatty acids at very high concentrations, or for long periods of time, can eventually induce beta-cell death and dysfunction in human islets and in animal models (Jeffrey et al. 2008). Clearly, a better understanding of the effects of lipids on human beta-cells from a large array of donors is urgently needed.

Evidence similarly points to a role for some amino acids in acute and chronic insulin secretion (Nair \& Short 2005). For example, arginine is a well-known insulin secretagogue used to 'maximally' stimulate insulin secretion in a clinical setting (Robertson 2007). Elevated circulating levels of branched-chain amino acids are associated with over-nutrition, obesity and type 2 diabetes (McCormack et al. 2013). Metabolomic profiling of 2422 Framingham Offspring individuals identified elevated levels of five branched-chain and aromatic amino acids (isoleucine, leucine, valine, tyrosine and phenylalanine) that were significantly associated with subsequent diabetes (Wang et al. 2011). Notably, branched-chain amino acids such as leucine can be powerful insulin secretagogues (van Loon et al. 2003). To date, no study has simultaneously compared the responsiveness to glucose, fatty acids and amino acids, but our anecdotal experience is that there is considerable variability in the relative responses to these macronutrient groups between individuals. Genetic profiling studies could be used to understand the mechanistic underpinnings of this variation. Answering this question could usher in a new era of nutrigenomics to minimize obesity and diabetes risk. If fats and proteins can stimulate robust insulin secretion in some individuals, it would mean that a one-size-fits-all prescription of simply avoiding excess carbohydrates would not be sufficient for these people. Maintaining insulin levels relatively in the healthy range might be more complex and individualized than once thought. It should be stressed that the healthy insulin range obviously has a minimum for each individual, below which diabetes occurs.

\section{Conclusions and future directions}

Long-term studies using ever more powerful animal models, as well as carefully defined human trials, are required to further test the hypothesis that hyperinsulinemia is a driving force in obesity, insulin

Published by Bioscientifica Ltd. 
resistance and type 2 diabetes and to determine its net contribution, which is likely to be context dependent. Although our published studies have demonstrated that preventing hyperinsulinemia can prevent obesity in euglycemic conditions, we have not yet shown that obesity can be treated by reducing insulin secretion in mice that have already gained weight or demonstrated that hyperinsulinemia has a similar role in a more typical scenario that includes dysglycemia. Clinical evidence to support reducing insulin as a therapy for obesity has been presented (Lunetta et al. 1996, Alemzadeh et al. 1998, Lustig et al. 2005), but conflicting data on specific patient populations have also been published (Brauner et al. 2016). Therefore, a focus on hyperinsulinemia as a target for obesity has not yet been widely adopted. It is likely that hyperinsulinemia contributes to the 'environmental' part of the obesity risk equation, as common variation in the INS gene has not been genetically associated with BMI or circulating triglycerides (http://www.type2diabetesgenetics.org). Nevertheless, insulin could be reduced in many individuals by adopting low-carbohydrate diets, timecontrolled feeding or high-intensity exercise (Holloszy 2005, Balkau et al. 2008, Hatori et al. 2012, Schugar \& Crawford 2012, Nelson et al. 2013, Longo \& Panda 2016). Work in this area has the potential to change the paradigms of obesity and diabetes pathophysiology and to provide people with personalized nutritional advice for weight loss and disease prevention based around the maintenance of insulin within a healthy range. Lifestyle changes aimed at preventing excess circulating insulin could be a key to living a healthy long life.

\section{Declaration of interest}

The authors declare that there is no conflict of interest that could be perceived as prejudicing the impartiality of this review.

\section{Funding}

Related work in the JDJ laboratory has been funded by the Canadian Institutes for Health Research, the Canadian Diabetes Association (CDA), and the Juvenile Diabetes Research Foundation. N M T was supported by a Natural Science and Engineering Council of Canada scholarship and a Four-Year Fellowship from the University of British Columbia. M M P is supported by a CDA Fellowship. S S is supported by a Benzon Foundation Fellowship.

\section{Acknowledgements}

The authors thank colleagues including Timothy Kieffer (University of British Columbia), Ernesto Bernal-Mizrachi (University of Miami), Patrick MacDonald (University of Alberta) and many others for stimulating discussions on the biology of insulin. They thank members of the Institute for Personalized Therapeutic Nutrition (University of British Columbia), including Sean McKelvey and Jonathan Little, for discussions on the nutritional implications of this research area.

\section{References}

Alemzadeh R, Jacobs W \& Pitukcheewanont P 1996 Antiobesity effect of diazoxide in obese zucker rats. Metabolism 45 334-341. (doi:10.1016/ S0026-0495(96)90287-5)

Alemzadeh R, Langley G, Upchurch L, Smith P \& Slonim AE 1998 Beneficial effect of diazoxide in obese hyperinsulinemic adults. Journal of Clinical Endocrinology and Metabolism 83 1911-1915. (10.1210/jc.83.6.1911)

Balkau B, Mhamdi L, Oppert JM, Nolan J, Golay A, Porcellati F, Laakso M, Ferrannini E \& EGIR-RISC Study Group 2008 Physical activity and insulin sensitivity: the RISC study. Diabetes $572613-2618$. (doi:10.2337/db07-1605)

Banting FG, Best CH, Collip JB, Campbell WR \& Fletcher AA 1922 Pancreatic extracts in the treatment of diabetes mellitus. Canadian Medical Association Journal 12 141-146.

Beith JL, Alejandro EU \& Johnson JD 2008 Insulin stimulates primary beta-cell proliferation via Raf-1 kinase. Endocrinology 149 2251-2260. (doi:10.1210/en.2007-1557)

Bengtsson M, Stahlberg A, Rorsman P \& Kubista M 2005 Gene expression profiling in single cells from the pancreatic islets of Langerhans reveals lognormal distribution of mRNA levels. Genome Research $\mathbf{1 5}$ 1388-1392. (doi:10.1101/gr.3820805)

Beranger GE, Karbiener M, Barquissau V, Pisani DF, Scheideler M, Langin D \& Amri EZ 2013 In vitro brown and 'brite'/'beige' adipogenesis: human cellular models and molecular aspects. Biochimica et Biophysica Acta 1831 905-914. (doi:10.1016/j.bbalip.2012.11.001)

Berglund ED, Li CY, Poffenberger G, Ayala JE, Fueger PT, Willis SE, Jewell MM, Powers AC \& Wasserman DH 2008 Glucose metabolism in vivo in four commonly used inbred mouse strains. Diabetes $\mathbf{5 7}$ 1790-1799. (doi:10.2337/db07-1615)

Bernal-Mizrachi E, Fatrai S, Johnson JD, Ohsugi M, Otani K, Han Z, Polonsky KS \& Permutt MA 2004 Defective insulin secretion and increased susceptibility to experimental diabetes are induced by reduced Akt activity in pancreatic islet beta cells. Journal of Clinical Investigation 114 928-936. (doi:10.1172/JCI200420016)

Berry R, Jeffery E \& Rodeheffer MS 2014 Weighing in on adipocyte precursors. Cell Metabolism 19 8-20. (doi:10.1016/j.cmet.2013.10.003)

Biddinger SB \& Kahn CR 2006 From mice to men: insights into the insulin resistance syndromes. Annual Review of Physiology 68 123-158. (doi:10.1146/annurev.physiol.68.040104.124723)

Boothe T, Lim GE, Cen H, Skovso S, Piske M, Li SN, Nabi IR, Gilon P \& Johnson JD 2016 Inter-domain tagging implicates caveolin-1 in insulin receptor trafficking and Erk signaling bias in pancreatic beta-cells. Molecular Metabolism 5 366-378. (doi:10.1016/j.molmet.2016.01.009)

Boucher J, Mori MA, Lee KY, Smyth G, Liew CW, Macotela Y, Rourk M, Bluher M, Russell SJ \& Kahn CR 2012 Impaired thermogenesis and adipose tissue development in mice with fat-specific disruption of insulin and IGF-1 signalling. Nature Communications 3902.

Brauner R, Serreau R, Souberbielle JC, Pouillot M, Grouazel S, Recasens C, Zerah M, Sainte-Rose C \& Treluyer JM 2016 Diazoxide in children with obesity after hypothalamic-pituitary lesions: a randomized, placebo-controlled trial. Journal of Clinical Endocrinology and Metabolism 101 4825-4833. (doi:10.1210/jc.2016-2126)

Brogiolo W, Stocker H, Ikeya T, Rintelen F, Fernandez R \& Hafen E 2001 An evolutionarily conserved function of the Drosophila insulin receptor and insulin-like peptides in growth control. Current Biology 11 213-221. (doi:10.1016/S0960-9822(01)00068-9)

Buyken AE, Goletzke J, Joslowski G, Felbick A, Cheng G, Herder C \& Brand-Miller JC 2014 Association between carbohydrate quality 
and inflammatory markers: systematic review of observational and interventional studies. American Journal of Clinical Nutrition 99 813-833. (doi:10.3945/ajcn.113.074252)

Carpentier A, Mittelman SD, Lamarche B, Bergman RN, Giacca A \& Lewis GF 1999 Acute enhancement of insulin secretion by FFA in humans is lost with prolonged FFA elevation. American Journal of Physiology 276 E1055-E1066.

Cavallo-Perin P, Bruno A, Scaglione L, Gruden G, Cassader M \& Pagano G 1993 Feedback inhibition of insulin and glucagon secretion by insulin is altered in abdominal obesity with normal or impaired glucose tolerance. Acta Diabetologica 30 154-158. (doi:10.1007/BF00572860)

Cheng Z, Tseng Y \& White MF 2010 Insulin signaling meets mitochondria in metabolism. Trends in Endocrinology and Metabolism 21 589-598. (doi:10.1016/j.tem.2010.06.005)

Chondronikola M, Volpi E, Borsheim E, Porter C, Saraf MK, Annamalai P, Yfanti C, Chao T, Wong D, Shinoda K, et al. 2016 Brown adipose tissue activation is linked to distinct systemic effects on lipid metabolism in humans. Cell Metabolism 23 1200-1206. (doi:10.1016/j.cmet.2016.04.029)

Clancy DJ, Gems D, Harshman LG, Oldham S, Stocker H, Hafen E, Leevers SJ \& Partridge L 2001 Extension of life-span by loss of CHICO, a Drosophila insulin receptor substrate protein. Science 292 104-106. (doi:10.1126/science.1057991)

Cook A \& Cowan C 2008 Adipose. In StemBook. Ed. The Stem Cell Research Community. Boston, MA, USA: Massachusetts General Hospital/Harvard Stem Cell Institute. (doi:10.3824/stembook.1.40.1)

Corkey BE 2012 Banting lecture 2011: hyperinsulinemia: cause or consequence? Diabetes 61 4-13. (doi:10.2337/db11-1483)

Cusin I, Terrettaz J, Rohner-Jeanrenaud F \& Jeanrenaud B 1990 Metabolic consequences of hyperinsulinaemia imposed on normal rats on glucose handling by white adipose tissue, muscles and liver. Biochemical Journal 267 99-103.

Czech MP, Tencerova M, Pedersen DJ \& Aouadi M 2013 Insulin signalling mechanisms for triacylglycerol storage. Diabetologia 56 949-964. (doi:10.1007/s00125-013-2869-1)

Dankner R, Chetrit A, Shanik MH, Raz I \& Roth J 2009 Basal-state hyperinsulinemia in healthy normoglycemic adults is predictive of type 2 diabetes over a 24-year follow-up: a preliminary report. Diabetes Care 32 1464-1466. (doi:10.2337/dc09-0153)

Deltour L, Leduque P, Blume N, Madsen O, Dubois P, Jami J \& Bucchini D 1993 Differential expression of the two nonallelic proinsulin genes in the developing mouse embryo. PNAS 90 527-531. (doi:10.1073/ pnas.90.2.527)

Deltour L, Montagutelli X, Guenet JL, Jami J \& Paldi A 1995 Tissue- and developmental stage-specific imprinting of the mouse proinsulin gene, Ins2. Developmental Biology 168 686-688. (doi:10.1006/dbio.1995.1114)

Dionne DA, Skovso S, Templeman NM, Clee SM \& Johnson JD 2016 Caloric restriction paradoxically increases adiposity in mice with genetically reduced insulin. Endocrinology 157 2724-2734. (doi:10.1210/en.2016-1102)

Duvillie B, Bucchini D, Tang T, Jami J \& Paldi A 1998 Imprinting at the mouse Ins2 locus: evidence for cis- and trans-allelic interactions. Genomics 47 52-57. (doi:10.1006/geno.1997.5070)

Ebbeling CB, Leidig MM, Feldman HA, Lovesky MM \& Ludwig DS 2007 Effects of a low-glycemic load vs low-fat diet in obese young adults: a randomized trial. JAMA 297 2092-2102. (doi:10.1001/ jama.297.19.2092)

Fan Y, Rudert WA, Grupillo M, He J, Sisino G \& Trucco M 2009 Thymusspecific deletion of insulin induces autoimmune diabetes. $E M B O$ Journal 28 2812-2824. (doi:10.1038/emboj.2009.212)

Fernandez AM \& Torres-Aleman I 2012 The many faces of insulinlike peptide signalling in the brain. Nature Reviews Neuroscience $\mathbf{1 3}$ 225-239. (doi:10.1038/nrn3209)

Fontana L, Partridge L \& Longo VD 2010 Extending healthy life span - from yeast to humans. Science 328 321-326. (doi:10.1126/ science.1172539)
Fontes G, Zarrouki B, Hagman DK, Latour MG, Semache M, Roskens V, Moore PC, Prentki M, Rhodes CJ, Jetton TL, et al. 2010 Glucolipotoxicity age-dependently impairs beta cell function in rats despite a marked increase in beta cell mass. Diabetologia 53 2369-2379. (doi:10.1007/s00125-010-1850-5)

Fu Z, Gilbert ER \& Liu D 2013 Regulation of insulin synthesis and secretion and pancreatic Beta-cell dysfunction in diabetes. Current Diabetes Reviews 9 25-53. (doi:10.2174/157339913804143225)

Fuente-Martin E, Argente-Arizon P, Ros P, Argente J \& Chowen JA 2013 Sex differences in adipose tissue: it is not only a question of quantity and distribution. Adipocyte 2 128-134. (doi:10.4161/adip.24075)

Genuth SM, Przybylski RJ \& Rosenberg DM 1971 Insulin resistance in genetically obese, hyperglycemic mice. Endocrinology 88 1230-1238. (doi:10.1210/endo-88-5-1230)

Gray SL, Donald C, Jetha A, Covey SD \& Kieffer TJ 2010 Hyperinsulinemia precedes insulin resistance in mice lacking pancreatic $\beta$-cell leptin signaling. Endocrinology $1514178-4186$. (doi:10.1210/en.2010-0102)

Grosse J, Heffron H, Burling K, Akhter Hossain M, Habib AM, Rogers GJ, Richards P, Larder R, Rimmington D, Adriaenssens AA, et al. 2014 Insulin-like peptide 5 is an orexigenic gastrointestinal hormone. PNAS 111 11133-11138. (doi:10.1073/pnas.1411413111)

Guerra C, Navarro P, Valverde AM, Arribas M, Bruning J, Kozak LP, Kahn CR \& Benito M 2001 Brown adipose tissue-specific insulin receptor knockout shows diabetic phenotype without insulin resistance. Journal of Clinical Investigation 108 1205-1213. (doi:10.1172/JCI13103)

Gunton JE, Kulkarni RN, Yim S, Okada T, Hawthorne WJ, Tseng YH, Roberson RS, Ricordi C, O'Connell PJ, Gonzalez FJ, et al. 2005 Loss of ARNT/HIF1beta mediates altered gene expression and pancreaticislet dysfunction in human type 2 diabetes. Cell 122 337-349. (doi:10.1016/j.cell.2005.05.027)

Hatori M, Vollmers C, Zarrinpar A, DiTacchio L, Bushong EA, Gill S, Leblanc M, Chaix A, Joens M, Fitzpatrick JA, et al. 2012 Timerestricted feeding without reducing caloric intake prevents metabolic diseases in mice fed a high-fat diet. Cell Metabolism 15 848-860. (doi:10.1016/j.cmet.2012.04.019)

Hay CW \& Docherty K 2006 Comparative analysis of insulin gene promoters: implications for diabetes research. Diabetes 55 3201-3213. (doi:10.2337/db06-0788)

Holloszy JO 2005 Exercise-induced increase in muscle insulin sensitivity. Journal of Applied Physiology 99 338-343. (doi:10.1152/ japplphysiol.00123.2005)

Jeffery E, Wing A, Holtrup B, Sebo Z, Kaplan JL, Saavedra-Pena R, Church CD, Colman L, Berry R \& Rodeheffer MS 2016 The adipose tissue microenvironment regulates depot-specific adipogenesis in obesity. Cell Metabolism 24 142-150. (doi:10.1016/j. cmet.2016.05.012)

Jeffrey KD, Alejandro EU, Luciani DS, Kalynyak TB, Hu X, Li H, Lin Y, Townsend RR, Polonsky KS \& Johnson JD 2008 Carboxypeptidase E mediates palmitate-induced beta-cell ER stress and apoptosis. PNAS 105 8452-8457. (doi:10.1073/pnas.0711232105)

Johnson AM \& Olefsky JM 2013 The origins and drivers of insulin resistance. Cell 152 673-684. (doi:10.1016/j.cell.2013.01.041)

Johnson JD, Bernal-Mizrachi E, Alejandro EU, Han Z, Kalynyak TB, Li H, Beith JL, Gross J, Warnock GL, Townsend RR, et al. 2006 Insulin protects islets from apoptosis via Pdx1 and specific changes in the human islet proteome. PNAS 103 19575-19580. (doi:10.1073/pnas.0604208103)

Katic M, Kennedy AR, Leykin I, Norris A, McGettrick A, Gesta S, Russell SJ, Bluher M, Maratos-Flier E \& Kahn CR 2007 Mitochondrial gene expression and increased oxidative metabolism: role in increased lifespan of fat-specific insulin receptor knock-out mice. Aging Cell 6 827-839. (doi:10.1111/j.1474-9726.2007.00346.x)

Kenyon C, Chang J, Gensch E, Rudner A \& Tabtiang R 1993 A C. elegans mutant that lives twice as long as wild type. Nature 366 461-464. (doi:10.1038/366461a0) 
Kersten S 2001 Mechanisms of nutritional and hormonal regulation of lipogenesis. EMBO Reports 2 282-286. (doi:10.1093/embo-reports/ kve071)

Khan FA, Goforth PB, Zhang M \& Satin LS 2001 Insulin activates ATP-sensitive $\mathrm{K}(+)$ channels in pancreatic beta-cells through a phosphatidylinositol 3-kinase-dependent pathway. Diabetes 50 2192-2198. (doi:10.2337/diabetes.50.10.2192)

Kido Y, Burks DJ, Withers D, Bruning JC, Kahn CR, White MF \& Accili D 2000 Tissue-specific insulin resistance in mice with mutations in the insulin receptor, IRS-1, and IRS-2. Journal of Clinical Investigation 105 199-205. (doi:10.1172/JCI7917)

Knutson VP, Ronnett GV \& Lane MD 1983 Rapid, reversible internalization of cell surface insulin receptors. Correlation with insulin-induced down-regulation. Journal of Biological Chemistry 258 12139-12142.

Kwok KH, Lam KS \& Xu A 2016 Heterogeneity of white adipose tissue: molecular basis and clinical implications. Experimental and Molecular Medicine 48 e215. (doi:10.1038/emm.2016.5)

Labbe SM, Caron A, Chechi K, Laplante M, Lecomte R \& Richard D 2016 Metabolic activity of brown, 'beige,' and white adipose tissues in response to chronic adrenergic stimulation in male mice. American Journal of Physiology: Endocrinology and Metabolism 311 E260-E268. (10.1152/ajpendo.00545.2015)

Lawlor DA \& Chaturvedi N 2006 Treatment and prevention of obesity - are there critical periods for intervention? International Journal of Epidemiology 35 3-9. (doi:10.1093/ije/dyi309)

Le Stunff C \& Bougnères P 1994 Early changes in postprandial insulin secretion, not in insulin sensitivity, characterize juvenile obesity. Diabetes 43 696-702.

Lee MJ, Wu Y \& Fried SK 2013 Adipose tissue heterogeneity: implication of depot differences in adipose tissue for obesity complications. Molecular Aspects of Medicine 34 1-11. (doi:10.1016/j.mam.2012.10.001)

Lee SH, Zabolotny JM, Huang H, Lee H \& Kim YB 2016 Insulin in the nervous system and the mind: functions in metabolism, memory, and mood. Molecular Metabolism 5 589-601. (doi:10.1016/j. molmet.2016.06.011)

Leibiger IB, Leibiger B \& Berggren PO 2008 Insulin signaling in the pancreatic beta-cell. Annual Review of Nutrition 28 233-251. (doi:10.1146/annurev.nutr.28.061807.155530)

Leroux L, Desbois P, Lamotte L, Duvillie B, Cordonnier N, Jackerott M, Jami J, Bucchini D \& Joshi RL 2001 Compensatory responses in mice carrying a null mutation for Ins1 or Ins2. Diabetes $\mathbf{5 0}$ (Supplement 1) S150-S153. (doi:10.2337/diabetes.50.2007.S150)

Li C, Ford ES, McGuire LC, Mokdad AH, Little RR \& Reaven GM 2006 Trends in hyperinsulinemia among nondiabetic adults in the U.S. Diabetes Care 29 2396-2402. (doi:10.2337/dc06-0289)

Lim GE, Albrecht T, Piske M, Sarai K, Lee JT, Ramshaw HS, Sinha S, Guthridge MA, Acker-Palmer A, Lopez AF, et al. 2015 14-3-3zeta coordinates adipogenesis of visceral fat. Nature Communications 6 7671. (doi:10.1038/ncomms8671)

Linde S, Nielsen JH, Hansen B \& Welinder BS 1989 Reversed-phase highperformance liquid chromatographic analyses of insulin biosynthesis in isolated rat and mouse islets. Journal of Chromatography $\mathbf{4 6 2}$ 243-254. (doi:10.1016/S0021-9673(00)91351-7)

Longo VD \& Panda S 2016 Fasting, circadian rhythms, and timerestricted feeding in healthy lifespan. Cell Metabolism 23 1048-1059. (doi:10.1016/j.cmet.2016.06.001)

Luciani DS \& Johnson JD 2005 Acute effects of insulin on beta-cells from transplantable human islets. Molecular and Cellular Endocrinology 241 88-98. (doi:10.1016/j.mce.2005.06.006)

Lunetta M, Di Mauro M, Le Moli R \& Burrafato S 1996 Long-term octreotide treatment reduced hyperinsulinemia, excess body weight and skin lesions in severe obesity with acanthosis nigricans. Journal of Endocrinological Investigation 19 699-703. (doi:10.1007/BF03349042)

Lustig RH, Greenway F, Velasquez-Mieyer P, Heimburger D, Schumacher D, Smith D, Smith W, Soler N, Warsi G, Berg W, et al. 2005 A multicenter, randomized, double-blind, placebo-controlled, dose-finding trial of a long-acting formulation of octreotide in promoting weight loss in obese adults with insulin hypersecretion. International Journal of Obesity 30 331-341. (doi:10.1038/sj.ijo.0803074)

Marsh BD, Marsh DJ \& Bergman RN 1986 Oscillations enhance the efficiency and stability of glucose disposal. American Journal of Physiology 250 E576-E582.

McAuley KA, Williams SM, Mann JI, Walker RJ, Lewis-Barned NJ, Temple LA \& Duncan AW 2001 Diagnosing insulin resistance in the general population. Diabetes Care 24 460-464.

McCarthy MI 2015 Genomic medicine at the heart of diabetes management. Diabetologia 58 1725-1729. (doi:10.1007/s00125-0153588-6)

McCormack SE, Shaham O, McCarthy MA, Deik AA, Wang TJ, Gerszten RE, Clish CB, Mootha VK, Grinspoon SK \& Fleischman A 2013 Circulating branched-chain amino acid concentrations are associated with obesity and future insulin resistance in children and adolescents. Pediatric Obesity 8 52-61. (doi:10.1111/j.2047-6310.2012.00087.x)

McGarry JD 1992 What if Minkowski had been ageusic? An alternative angle on diabetes. Science 258 766-770. (doi:10.1126/ science.1439783)

Mehran AE, Templeman NM, Brigidi GS, Lim GE, Chu KY, Hu X, Botezelli JD, Asadi A, Hoffman BG, Kieffer TJ, et al. 2012 Hyperinsulinemia drives diet-induced obesity independently of brain insulin production. Cell Metabolism 16 723-737. (doi:10.1016/j. cmet.2012.10.019)

Melloul D, Marshak S \& Cerasi E 2002 Regulation of insulin gene transcription. Diabetologia 45 309-326. (doi:10.1007/s00125-001-0728-y)

Meur G, Qian Q, da Silva Xavier G, Pullen TJ, Tsuboi T, McKinnon C, Fletcher L, Tavare JM, Hughes S, Johnson P, et al. 2011 Nucleocytosolic shuttling of FoxO1 directly regulates mouse Ins2 but not Ins1 gene expression in pancreatic beta cells (MIN6). Journal of Biological Chemistry 286 13647-13656. (doi:10.1074/jbc.M110.204248)

Nair KS \& Short KR 2005 Hormonal and signaling role of branched-chain amino acids. Journal of Nutrition 135 1547S-1552S.

Nakae J, Kido Y \& Accili D 2001 Distinct and overlapping functions of insulin and IGF-I receptors. Endocrine Reviews 22 818-835. (doi:10.1210/edrv.22.6.0452)

Nelson RK, Horowitz JF, Holleman RG, Swartz AM, Strath SJ, Kriska AM \& Richardson CR 2013 Daily physical activity predicts degree of insulin resistance: a cross-sectional observational study using the 2003-2004 National Health and Nutrition Examination Survey. International Journal of Behavioral Nutrition and Physical Activity 1010. (doi:10.1186/1479-5868-10-10)

Nolan CJ, Damm P \& Prentki M 2011 Type 2 diabetes across generations: from pathophysiology to prevention and management. Lancet $\mathbf{3 7 8}$ 169-181. (doi:10.1016/S0140-6736(11)60614-4)

Nolan CJ, Ruderman NB \& Prentki M 2013 Intensive insulin for type 2 diabetes: the risk of causing harm. Lancet Diabetes and Endocrinology $\mathbf{1}$ 9-10. (doi:10.1016/S2213-8587(13)70027-5)

Nolan CJ, Ruderman NB, Kahn SE, Pedersen O \& Prentki M 2015 Insulin resistance as a physiological defense against metabolic stress: implications for the management of subsets of type 2 diabetes. Diabetes 64 673-686. (doi:10.2337/db14-0694)

O'Rahilly S, Turner RC \& Matthews DR 1988 Impaired pulsatile secretion of insulin in relatives of patients with non-insulin-dependent diabetes. New England Journal of Medicine 318 1225-1230. (10.1056/ nejm198805123181902)

Odeleye OE, de Courten M, Pettitt DJ \& Ravussin E 1997 Fasting hyperinsulinemia is a predictor of increased body weight gain and obesity in Pima Indian children. Diabetes 46 1341-1345. (doi:10.2337/diab.46.8.1341)

ORIGIN Trial Investigators, Gerstein HC, Bosch J, Dagenais GR, Diaz R, Jung H, Maggioni AP, Pogue J, Probstfield J, Ramachandran A, et al. 2012 Basal insulin and cardiovascular and other outcomes in dysglycemia. New England Journal of Medicine 367 319-328. (doi:10.1056/NEJMoa1203858) http://joe.endocrinology-journals.org

DOI: 10.1530/JOE-16-0449
๑) 2017 Society for Endocrinology Printed in Great Britain 
Paolisso G, Gambardella A, Amato L, Tortoriello R, D'Amore A, Varricchio M \& D'Onofrio F 1995 Opposite effects of short- and long-term fatty acid infusion on insulin secretion in healthy subjects Diabetologia 38 1295-1299. (doi:10.1007/BF00401761)

Pedersen DJ, Guilherme A, Danai LV, Heyda L, Matevossian A, Cohen J, Nicoloro SM, Straubhaar J, Noh HL, Jung D, et al. 2015 A major role of insulin in promoting obesity-associated adipose tissue inflammation. Molecular Metabolism 4 507-518. (doi:10.1016/j. molmet.2015.04.003)

Pierce SB, Costa M, Wisotzkey R, Devadhar S, Homburger SA, Buchman AR, Ferguson KC, Heller J, Platt DM, Pasquinelli AA, et al. 2001 Regulation of DAF-2 receptor signaling by human insulin and ins-1, a member of the unusually large and diverse C. elegans insulin gene family. Genes and Development 15 672-686. (doi:10.1101/gad.867301)

Pittas AG, Das SK, Hajduk CL, Golden J, Saltzman E, Stark PC, Greenberg AS \& Roberts SB 2005 A low-glycemic load diet facilitates greater weight loss in overweight adults with high insulin secretion but not in overweight adults with low insulin secretion in the CALERIE trial. Diabetes Care 28 2913-2941.

Prentki M \& Nolan CJ 2006 Islet beta cell failure in type 2 diabetes. Journal of Clinical Investigation 116 1802-1812. (doi:10.1172/JCI29103)

Rajan S, Shankar K, Beg M, Varshney S, Gupta A, Srivastava A, Kumar D, Mishra RK, Hussain Z, Gayen JR, et al. 2016 Chronic hyperinsulinemia reduces insulin sensitivity and metabolic functions of brown adipocyte. Journal of Endocrinology 230 275-290. (doi:10.1530/JOE-16-0099)

Rideout EJ, Narsaiya MS \& Grewal SS 2015 The sex determination gene transformer regulates male-female differences in Drosophila body size. PLoS Genetics 11 e1005683. (doi:10.1371/journal.pgen.1005683)

Robertson RP 2007 Estimation of beta-cell mass by metabolic tests: necessary, but how sufficient? Diabetes 56 2420-2424. (doi:10.2337/ db07-0742)

Saltiel AR \& Kahn CR 2001 Insulin signalling and the regulation of glucose and lipid metabolism. Nature 414 799-806. (doi:10.1038/414799a)

Satin LS, Butler PC, Ha J \& Sherman AS 2015 Pulsatile insulin secretion, impaired glucose tolerance and type 2 diabetes. Molecular Aspects of Medicine 42 61-77. (doi:10.1016/j.mam.2015.01.003)

Schugar RC \& Crawford PA 2012 Low-carbohydrate ketogenic diets, glucose homeostasis, and nonalcoholic fatty liver disease. Current Opinion in Clinical Nutrition and Metabolic Care 15 374-380. (doi:10.1097/MCO.0b013e3283547157)

Schwartz MW \& Porte D Jr 2005 Diabetes, obesity, and the brain. Science 307 375-379. (doi:10.1126/science.1104344)

Shabanpoor F, Separovic F \& Wade JD 2009 The human insulin superfamily of polypeptide hormones. Vitamins and Hormones $\mathbf{8 0}$ 1-31. (10.1016/s0083-6729(08)00601-8)

Shanik MH, Xu Y, Skrha J, Dankner R, Zick Y \& Roth J 2008 Insulin resistance and hyperinsulinemia: is hyperinsulinemia the cart or the horse? Diabetes Care 31 (Supplement 2) S262-S268. (doi:10.2337/ dc08-s264)

Shiao MS, Liao BY, Long M \& Yu HT 2008 Adaptive evolution of the insulin two-gene system in mouse. Genetics 178 1683-1691. (doi:10.1534/genetics.108.087023)

Skovso S, Damgaard J, Fels JJ, Olsen GS, Wolf XA, Rolin B \& Holst JJ 2015 Effects of insulin therapy on weight gain and fat distribution in the HF/HS-STZ rat model of type 2 diabetes. International Journal of Obesity 39 1531-1538.

Soares MB, Schon E, Henderson A, Karathanasis SK, Cate R, Zeitlin S, Chirgwin J \& Efstratiadis A 1985 RNA-mediated gene duplication: the rat preproinsulin I gene is a functional retroposon. Molecular and Cellular Biology 5 2090-2103. (doi:10.1128/MCB.5.8.2090)

Softic S, Boucher J, Solheim MH, Fujisaka S, Haering MF, Homan EP, Winnay J, Perez-Atayde AR \& Kahn CR 2016 Lipodystrophy due to

http://joe.endocrinology-journals.org

DOI: $10.1530 / J O E-16-0449$
(C) 2017 Society for Endocrinology Printed in Great Britain adipose tissue specific insulin receptor knockout results in progressive NAFLD. Diabetes 65 2187-2200. (doi:10.2337/db16-0213)

Staaf J, Ubhayasekera SJ, Sargsyan E, Chowdhury A, Kristinsson H, Manell H, Bergquist J, Forslund A \& Bergsten P 2016 Initial hyperinsulinemia and subsequent beta-cell dysfunction is associated with elevated palmitate levels. Pediatric Research 80 267-274. (doi:10.1038/pr.2016.80)

Stockhorst U, de Fries D, Steingrueber HJ \& Scherbaum WA 2004 Insulin and the CNS: effects on food intake, memory, and endocrine parameters and the role of intranasal insulin administration in humans. Physiology and Behavior 83 47-54. (doi:10.1016/S0031-9384(04)00348-8)

Szabat M, Lynn FC, Hoffman BG, Kieffer TJ, Allan DW \& Johnson JD 2012 Maintenance of beta-cell maturity and plasticity in the adult pancreas: developmental biology concepts in adult physiology. Diabetes 61 1365-1371. (doi:10.2337/db11-1361)

Szabat M, Page MM, Panzhinskiy E, Skovso S, Mojibian M, Fernandez-Tajes J, Bruin JE, Bround MJ, Lee JT, Xu EE, et al. 2016 Reduced insulin production relieves endoplasmic reticulum stress and induces beta cell proliferation. Cell Metabolism 23 179-193. (doi:10.1016/j.cmet.2015.10.016)

Tabak AG, Jokela M, Akbaraly TN, Brunner EJ, Kivimaki M \& Witte DR 2009 Trajectories of glycaemia, insulin sensitivity, and insulin secretion before diagnosis of type 2 diabetes: an analysis from the Whitehall II study. Lancet 373 2215-2221. (doi:10.1016/S0140-6736(09)60619-X)

Taniguchi CM, Emanuelli B \& Kahn CR 2006 Critical nodes in signalling pathways: insights into insulin action. Nature Reviews Molecular Cell Biology 7 85-96. (doi:10.1038/nrm1837)

Templeman NM, Clee SM \& Johnson JD 2015 Suppression of hyperinsulinaemia in growing female mice provides long-term protection against obesity. Diabetologia 58 2392-2402. (doi:10.1007/ s00125-015-3676-7)

Templeman NM, Mehran AE \& Johnson JD 2016 Hyper-variability in circulating insulin, high fat feeding outcomes, and effects of reducing Ins2 dosage in male Ins1-null mice in a specific pathogen-free facility. PLOS ONE 11 e0153280. (doi:10.1371/journal.pone.0153280)

Thorens B, Tarussio D, Maestro MA, Rovira M, Heikkila E \& Ferrer J 2015 Ins1(Cre) knock-in mice for beta cell-specific gene recombination. Diabetologia 58 558-565. (doi:10.1007/s00125-014-3468-5)

van Heemst D 2010 Insulin, IGF-1 and longevity. Aging and Disease $\mathbf{1}$ 147-157.

van Loon LJ, Kruijshoop M, Menheere PP, Wagenmakers AJ, Saris WH \& Keizer HA 2003 Amino acid ingestion strongly enhances insulin secretion in patients with long-term type 2 diabetes. Diabetes Care 26 625-630. (doi:10.2337/diacare.26.3.625)

Wang TJ, Larson MG, Vasan RS, Cheng S, Rhee EP, McCabe E, Lewis GD, Fox CS, Jacques PF, Fernandez C, et al. 2011 Metabolite profiles and the risk of developing diabetes. Nature Medicine 17 448-453. (doi:10.1038/nm.2307)

Wang M, Li J, Lim GE \& Johnson JD 2013 Is dynamic autocrine insulin signaling possible? A mathematical model predicts picomolar concentrations of extracellular monomeric insulin within human pancreatic islets. PLOS ONE 8 e64860. (doi:10.1371/journal. pone.0064860)

Wentworth BM, Schaefer IM, Villa-Komaroff L \& Chirgwin JM 1986 Characterization of the two nonallelic genes encoding mouse preproinsulin. Journal of Molecular Evolution 23 305-312. (doi:10.1007/BF02100639)

Werner H, Weinstein D \& Bentov I 2008 Similarities and differences between insulin and IGF-I: structures, receptors, and signalling pathways. Archives of Physiology and Biochemistry 114 17-22. (doi:10.1080/13813450801900694)

White MF 2003 Insulin signaling in health and disease. Science $\mathbf{3 0 2}$ 1710-1711. (doi:10.1126/science.1092952)

Received in final form 16 December 2016

Accepted 3 January 2017

Accepted Preprint published online 4 January 2017

Published by Bioscientifica Ltd. 